\title{
The Costa Rican General Elections of 6 February $1994^{*}$
}

\section{By: FABRICE EDOUARD LEHOUCQ}

Lehoucq, Fabrice. "The Costa Rican General Elections of 1994," Electoral Studies, Vol. 14, No. 1 (March 1995): 69-72.

Made available courtesy of ELSEVIER: http://www.elsevier.com/wps/find/journaldescription.cws home/30412/description\#description

***Note: Figures may be missing from this format of the document

On Sunday, 6 February 1994, elections were held in Costa Rica to elect a president, all 57 members of the Legislative Assembly and to fill 953 municipal seats (the rigidores and sindicos of cantones) as well as an equal number of their alternates. José Maria Figueres Olsen - the son of the charismatic leader that helped to found the National Liberation Party (PLN) - led this party to a narrow victory over Miguel Angel Rodriguez, the candidate of the Social Christian Unity Party (PUSC), the party of President Radael Angel Calderón Fournier (1990-4). This highly contested race also furnished the PLN with the largest plurality of deputies in the Legislative Assembly. Results of presidential and legislative races are summarized in the tables found at the end of this brief note.

\section{Background}

These elections marked the eleventh consecutive and quadrennially-scheduled occasion during which all Costa Ricans above the age of 20 (lowered to 18 in 1971) have cast ballots in fair and competitive elections for public officials. They also maintained a pattern of importance to Costa Rican political analysts: namely, that the opposition to PLN has never been able to elect a successor while in control of the presidency. Only the PLN has succeeded in retaining control of the presidency for two consecutive terms, in 1974, when Daniel Oduber Quirós succeeded the well-known father of the current president-elect and in 1986, when Oscar Arias Sanchez (later awarded a Nobel Peace Prize) assumed power after the administration of Luis Alberto Monge Alvarez. Finally, the 1994 elections are characterized by the disappearance of the Costa Rican left. The 4 seats not captured by the PLN and the PUSC belong to regional or non-Marxist parties.

\section{The 1994 Campaign}

Like most Costa Rican electoral campaigns, this one was largely devoid of programmatic debate. Indeed, the partisan-inspired attacks on each candidate were apparently nastier than usual. PUSC supporters relentlessly attacked Figueres Olsen; their accusations centered on his relationship with a mining concern that allegedly hoodwinked foreign investors. Most importantly, they struggled to raise doubts about his integrity by constantly reminding voters that in 1973, while a young lieutenant in the Civil Guard, Figueres Olsen was the last person seen in the company of a

\footnotetext{
* This note is based upon conversations with Costa Rican social scientists as well as reports published in La Nación (San Jose) and circulated on the CENTAM-L list on internet. I thank Professors Ivan Molina Jimenez and Eugenia Rodriguez Sáenz for swift replies to my recent questions about the election.
} 
citizen jailed for links to the drug trade and later found dead (el caso del "chemise"). Somewhat less successfully, PLN campaign organizers accused Rodriguez of financial improprieties while working with a cattle-exporting firm and for being a cold technocrat out-of-touch with the preoccupations of ordinary Costa Ricans.

Though neither candidate quarreled with the prevailing neoliberal orthodoxy of austerity and continued structural adjustment, the parties did offer voters somewhat different policy choices. Rodriguez promised to accelerate neoliberal reform in Costa Rica by raising the specter of privatizing the state-owned electricity and telephone companies and with further reductions in state support of the national education system and the social security institute. While never suggesting that the structural adjustment of the economy be abandoned, Figueres Olsen did reiterate his party's historical commitment to a better life for most Costa Ricans. His campaign message appeared to be that, though necessary, reform of the Costa Rican economy should not proceed at the expense of the poorest Costa Ricans.

The race for the 1994 presidency remained close and, in the last weeks of the campaign, uncertain. In the months before the election, opinion polls furnished each of the leading candidates with slim leads that often were not greater than the statistical margin of error. This appears to be a product of the fact that many Costa Ricans remained uninterested in the choices they were offered by the two major parties of their country. That both candidates were accused of improprieties undoubtedly fueled the indecisiveness of many voters and encouraged party loyalists to question their longstanding partisan commitments. In the end, however, the name appeal of Figueres Olsen, along with his party affiliation, appears to have swayed a bare majority of voters to reaffirm their links with the party so long associated with the consolidation of the welfare state in Costa Rica.

Available surveys seemingly uphold the plausibility of this interpretation. An exit poll conducted of voters by UNIMER indicated that a majority of citizens casting ballots for Figueres Olsen did so out of loyalty to the PLN and had decided to do so before June 1993, when this party held its convention to select candidates for legislative office. Only a minority backed Figueres because of his own record. The same poll also discovered that a majority of citizens that cast ballots in favor of Rodriguez were motivated by positive evaluations of this candidate's personal qualifications. Unlike supporters of the PLN, most PUSC voters were less motivated by Rodriguez's partisan affiliation than by other, more personality-centered characteristics.

\section{Electoral Laws}

The 1949 constitution awards the presidency to the candidate that receives the largest number of valid votes (which equals the total number of ballots cast minus anulled and blank votes) and at least 40 per cent of said vote. Should no candidate satisfy these conditions, a popular run-off is held between the two candidates garnering the largest number of votes. A run-off for the presidency has never become necessary since promulgation of the existing constitution. Since a constitutional reform enacted in 1969 (and with grandfather clauses for then living expresidents), presidents are prohibited from ever again running for this office.

Legislative deputies serve four-year terms simultaneously with that of the president and are elected from seven provincial and multimember districts employing the closed-list and least 
remainders version of proportional representation. Though deputies may run for re-election, they must wait a term before doing so.

Citizens use separate ballots to vote for presidents and legislators. In the 1994 elections, 16 per cent of Rodriguez's supporters voted for other parties in legislative elections while 11 per cent of Figueres Olsen's cast ballots for non-PLN candidates in such elections. Split-ticket voting has contributed to the election of chief executives that cannot rely upon stable legislative majorities to enact their programs. Including the results of the most recent elections, five Costa Rican presidents have led minority governments.

Reform of the deputy selection process is currently underway. Critics of the prevailing system argue that it maintains the influence of party leaders and local political machines, who prefer to have an Assembly packed with pliant deputies concerned with little more than delivering pork for their constituents. Along with disgruntled and defeated candidates for party lists, they have called for -democratizing" party conventions (only candidates for presidential office, and only since the late 1970s, are elected in North-American styled primaries).

Earlier last year, the PLN decided that it will hold primaries for its 1998 list of legislative candidates. The PUSC also appears to be moving to opening its process of selecting congressional nominees. Within the next four years, the Electoral Code also may be amended to allow citizens, on election day, to cast ballots for particular individuals from the lists of legislative candidates supplied by parties. How the candidate selection process will be reformed, and determining its impact on party behavior, awaits systematic reflection. 